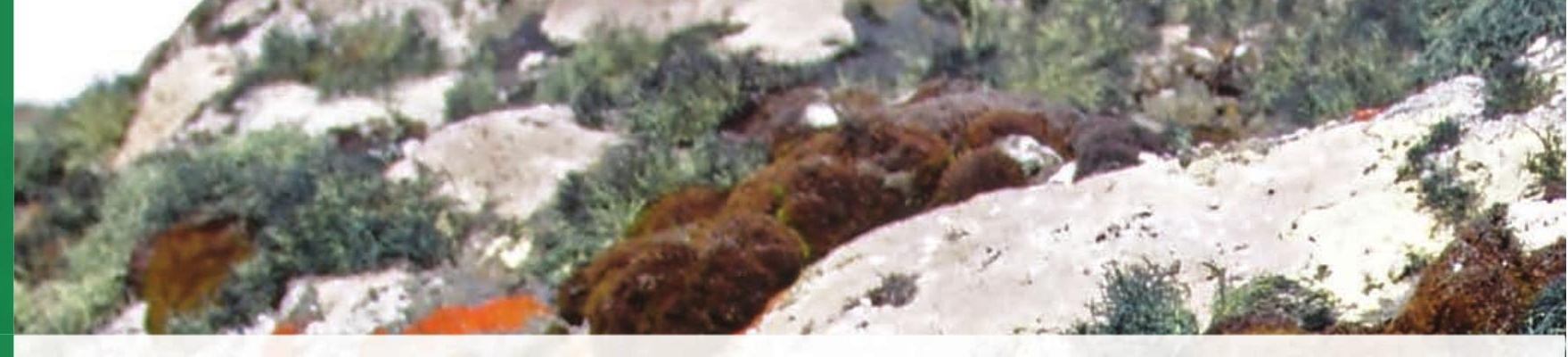

\title{
INFLUENCE OF SEA SURFACE TEMPERATURE ON PELAGIC SEABIRD DISTRIBUTION IN THE SOUTH ATLANTIC OCEAN
}

\author{
Victória Renata Fontoura Benemann ${ }^{1 *}$, Elisa de Souza Petersen¹, Lucas Krüger² \& Maria Virginia Petry \\ 'Universidade do Vale do Rio dos Sinos - UNISINOS. Laboratório de Ornitologia e Animais Marinhos. \\ Av. Unisinos, n 950, Cristo Rei, 93022-000, São Leopoldo, Rio Grande do Sul, Brazil. \\ ${ }^{2}$ MARE - Centro do Mar e Ambiente, Faculdade de Ciências e Tecnologia, \\ Universidade de Coimbra, 3004-517 Coimbra, Portugal. \\ *e-mail: victoriabenemann@gmail.com \\ https://doi.org/10.4322/apa.2016.002
}

\begin{abstract}
Seabird distribution is mostly related to high primary productivity zones, as well as to abiotic factors, such as hydrographic conditions. This study aimed at evaluating the influence of sea surface temperature on Antarctic and sub-Antarctic seabirds in the South Atlantic Ocean. Sampling was conducted on board between Rio Grande, Brazil, and Antarctica from 2009 to 2012. A PCA was performed to identify the species associations and Linear Regressions were used to identify the relation with sea surface temperature. We registered 22 Procellariiformes species, belonging to three families: Procellariidae ( $n=13)$, Diomedeidae $(n=7)$, and Hydrobatidae $(n=2)$. Three distinct species groups were identified, and two presented a significant relationship with sea surface temperature.
\end{abstract}

Keywords: Procellariiformes, SST, Southern Ocean, Sub-Antarctic

\section{Introduction}

The at-sea distribution of seabirds is constantly regulated by biotic and abiotic factors. During the non-breeding season, seabirds disperse over wide distances and their distribution is mainly influenced by the availability of prey (Péron et al., 2010; Krüger \& Petry, 2011; Ribic et al., 2011). Hydrographic conditions, such as sea surface temperature (SST), are determining factors that regulate the entire marine environment, influencing the distribution and population dynamics of top predator species; however, the species may respond in different ways to these variables (Garthe, 1997; Péron et al., 2010; Krüger \& Petry, 2011).

Under a warming ocean scenario, the understanding of how seabird distribution is related to climate is of fundamental importance (Grémillet \& Boulinier, 2009), considering that species seem to be changing their distribution accordding to changes in the availability of prey as a result of oceanographic regime shifts (Péron et al., 2010; Weimerskirch et al., 2012).
The aim of this study is to evaluate the distribution of Procellariiformes on a latitudinal gradient of sea surface temperature (SST) between southern South America and Antarctica and investigate the relationship between SST and each seabird species.

\section{Materials and Methods}

Data was collected aboard the ships NapOc Ary Rongel and NPo Almirante Maximiano during displacement between Rio Grande, south of Brazil, and South Shetland Islands, Antarctica, from 2009 to 2012 Antarctic Expeditions, in the austral summer of each year. Ten-minute censuses were conducted every hour and a half only on clear days, when visibility conditions ensured the correct identification of birds. All birds within $300 \mathrm{~m}$ from the ship deck were counted (Tasker et al., 1984). Birds identified as ship-followers were excluded from the analysis to avoid recounting. The temperature data (SST) were collected from the ships. 


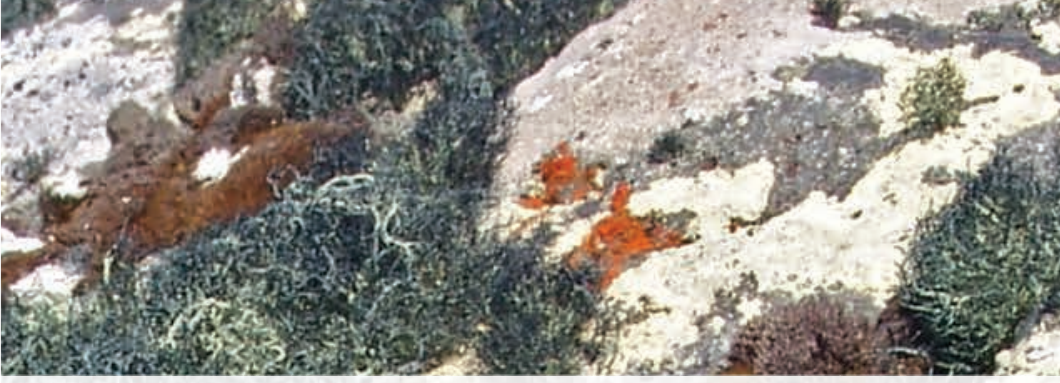

A categorical Principal Component Analysis (PCA) was applied to identify seabird assemblages. PCA is a multivariate technique that allows reduction of information on dimensions (axes) representing linear combinations of the original variables (in this case, species abundance). The categorical PCA ranks numeric variables, thus allowing better control of dimensional distortions as a consequence of lack of multivariate normality, which is usually common on count data. The scores obtained from the PCA were used in Linear Regressions to test the association of these assemblages with the SST, assuming statistical significance at $p<0.05$. The analysis was performed using the SPSS 18.0 statistical software.

\section{Results}

A total of 22 Procellariiformes species from three families were recorded: Procellariidae $(n=13)$, Diomedeidae $(\mathrm{n}=7)$, and Hydrobatidae $(\mathrm{n}=2)$, totaling 6446 individuals exemplified on Figure 1, where 4 species are shown. The most abundant species were Daption capense $(\mathrm{n}=1492)$, Pachyptila sp. $(\mathrm{n}=1488)$, and Thalassarche melanophrys $(\mathrm{n}=1311)$, taking into account the cumulative abundance along the year (Table 1 ).

SST varied from $-0.5^{\circ} \mathrm{C}\left(59^{\circ} \mathrm{S}\right)$ to $21.4^{\circ} \mathrm{C}\left(34^{\circ} \mathrm{S}\right)$ along all measurements. The PCA axes explained $15.79 \%$ of data variance (Axis $1=8.19 \%$ and Axis $2=7.59 \%$ ). Three species groups were revealed. Group I presented a negative correlation with Axis 1, group II presented a positive correlation with Axis 1, and group III presented a positive correlation with Axis 2 (Figure 2). Axis 1 presented significant negative regression with temperature $\left(R^{2}=0.186\right.$, $\mathrm{F}=34.912$, Slope $=-0.82, p<0.001)$, whereas Axis $2 \mathrm{did}$ not present a correlation with temperature $\left(\mathrm{R}^{2}=0.004, \mathrm{~F}=0.566\right.$, Slope $=0.15, p=0.453$ ). Consequently, group I is composed of species associated with warmer SST, whereas group II is composed of species associated with colder SST. Group III is not temperature related.

\section{Discussion and Conclusion}

Most species recorded in this study present circumpolar, subtropical distribution around the Atlantic, Indian, and Pacific Oceans and breed on Sub-Antarctic and/or Antarctic islands, except for Puffinus puffinus, which breeds in the Northern Hemisphere and spends the winters in South Atlantic waters during migration. Generally, the species relation with temperature seems to be consistent with knowledge on the latitudinal distribution of species (IUCN 2013).

South Atlantic temperatures are in a rising trend along the coast of South America (Grémillet \& Boulinier, 2009; Arruda \& Lentini, 2013) and there are clear abundance and distribution shifts in seabird communities because of changes in water temperature. In the past two decades, there was a decrease in the abundance of several species (Diomeda exulans, Procellaria aequinoctialis, Macronectes sp., Thalassarche chlororhynchos. and Pterodroma mollis) in the South Oceans due to SST warming (Péron et al., 2010). Changes in hydrographic conditions also affect species behavior. For example, foraging distribution of Diomedea exulans is enhancing to the South (Weimerskirch et al., 2012),
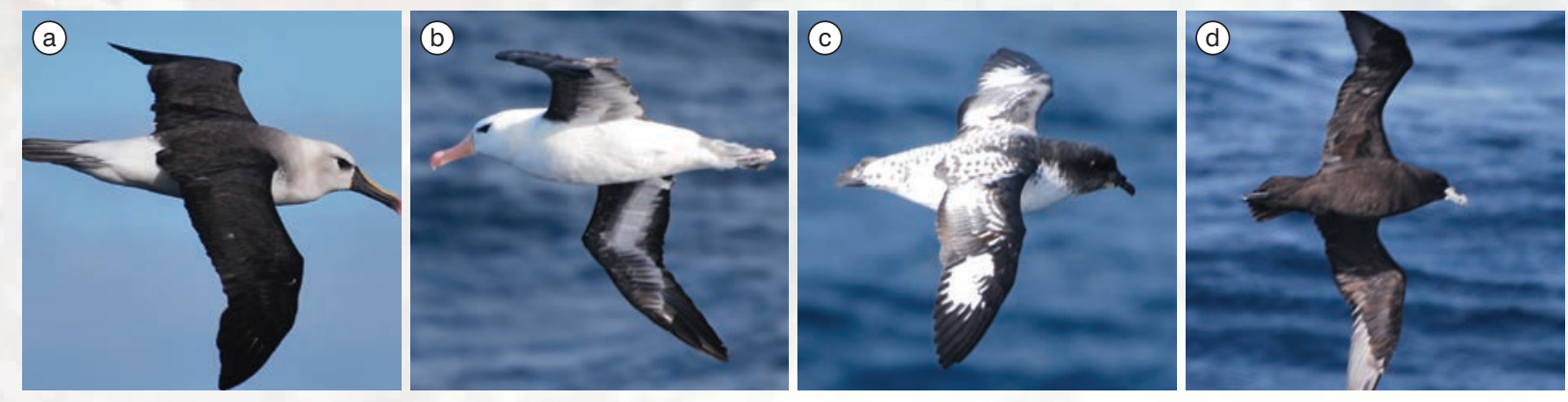

Figure 1. Examples of seabird species recorded: (a) Thalassarche chlororhynchos, (b) Thalassarche melanophrys, (c) Daption capense, (d) Procellaria aequinoctialis. 


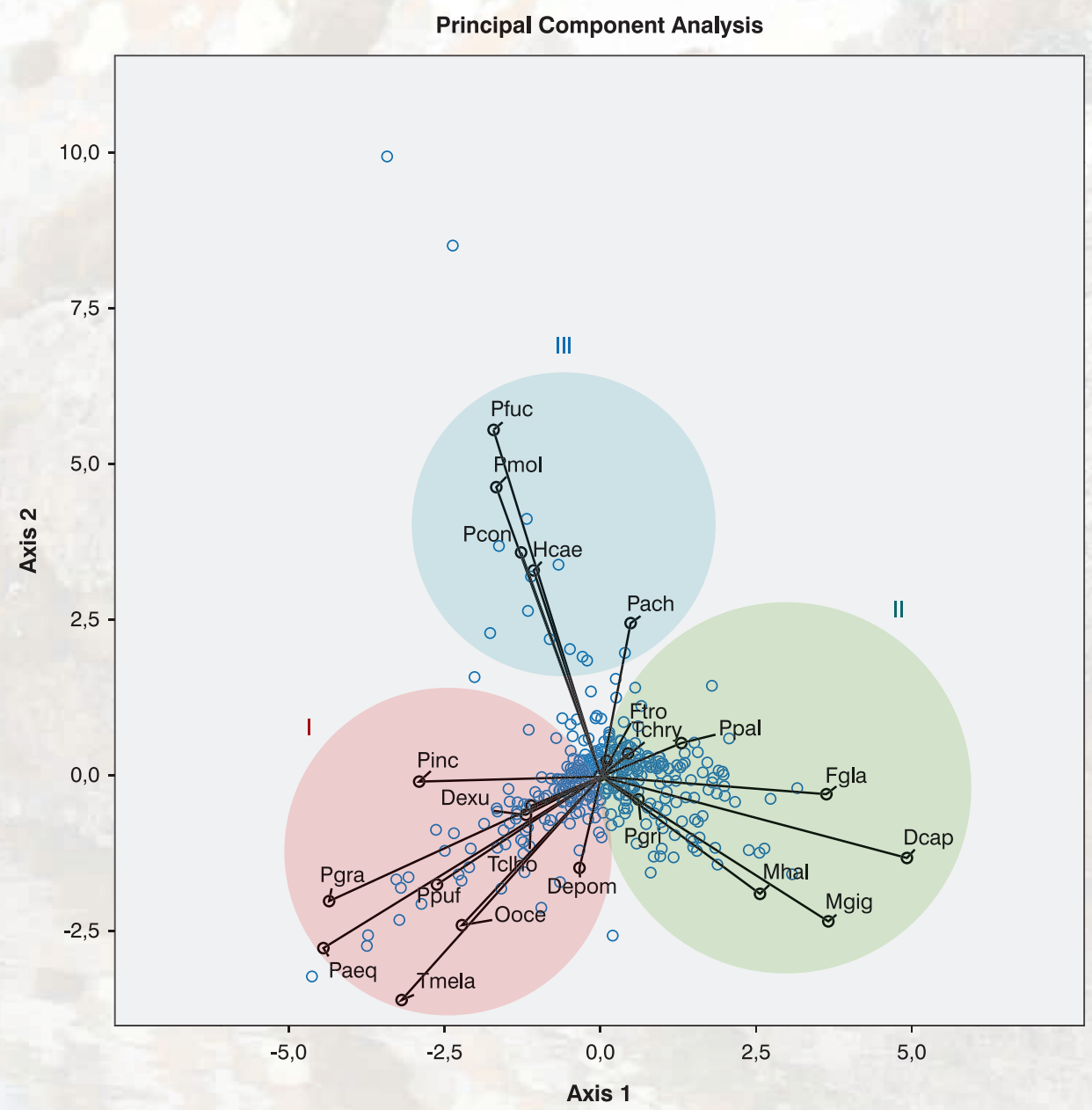

Figure 2. Species Principal Component Analysis. Associations I and II represent the "warm" and "cold" groups, respectively. Pfuc = Phoebetria fusca; Ppal =P. palpebrata; Tchlo = Thalassarche chlororhynchos; Tmela = T. melanophrys; Tchry = T. chlororhynchos; Depom = Diomedea epomophora; Dexu = D. exulans; Mgig = Macronectes giganteus; Mhal = M. halli; Fgla = Fulmarus glacialoides; Dcap = Daption capense; Pmol = Pterodroma mollis; Pinc = P. incerta; Hcae $=$ Halobaena caerulea; Pach $=$ Pachyptila $\mathrm{sp} . ;$ Paeq $=$ Procellaria aequinoctialis $;$ Pcon $=$ P. conspicillata; Pgri $=$ Puffinus griseus $;$ Pgra $=$ P. gravis; Ppuf $=$ P. puffinus; Ftro = Fregetta tropica; Ooce = Oceanites oceanicus.

Table 1. Species associations and total abundance. I = warm group, ||$=$ cold group.

\begin{tabular}{|c|c|c|c|c|c|}
\hline \multicolumn{2}{|l|}{ Group I } & \multicolumn{2}{|l|}{ Group II } & \multicolumn{2}{|l|}{ Group III } \\
\hline Species & $\mathbf{n}$ & Species & $\mathbf{n}$ & Species & $\mathbf{n}$ \\
\hline Thalassarche chlororhynchos & 25 & Phoebetria palpebrata & 12 & Phoebetria fusca & 3 \\
\hline T. melanophrys & 1311 & Thalassarche chrysostoma & 35 & Pterodroma mollis & 4 \\
\hline Diomedea epomophora & 68 & Macronectes giganteus & 595 & Halobaena caerulea & 36 \\
\hline D. exulans & 66 & M. halli & 44 & Pachyptila sp. & 1488 \\
\hline Pterodroma incerta & 178 & Fulmarus glacialoides & 154 & Procellaria conspicillata & 4 \\
\hline Procellaria aequinoctialis & 394 & Daption capense & 1492 & & \\
\hline Puffinus gravis & 300 & Puffinus griseus & 37 & & \\
\hline P. puffinus & 5 & Fregetta tropica & 63 & & \\
\hline Oceanites oceanicus & 132 & & & & \\
\hline
\end{tabular}


